Discussion Paper No. 02-25

\title{
Dismantling of a Breakthrough: \\ The Kyoto Protocol - Just Symbolic Policy!
}

Christoph Böhringer and Carsten Vogt

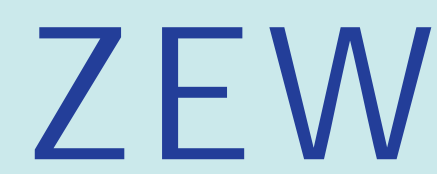

Zentrum für Europäische Wirtschaftsforschung $\mathrm{GmbH}$

Centre for European Economic Research 
Discussion Paper No. 02-25

\title{
Dismantling of a Breakthrough: The Kyoto Protocol - Just Symbolic Policy!
}

\author{
Christoph Böhringer and Carsten Vogt
}

Download this ZEW Discussion Paper from our ftp server:

ftp://ftp.zew.de/pub/zew-docs/dp/dp0225.pdf

Die Discussion Papers dienen einer möglichst schnellen Verbreitung von neueren Forschungsarbeiten des ZEW. Die Beiträge liegen in alleiniger Verantwortung der Autoren und stellen nicht notwendigerweise die Meinung des ZEW dar.

Discussion Papers are intended to make results of ZEW research promptly available to other economists in order to encourage discussion and suggestions for revisions. The authors are solely responsible for the contents which do not necessarily represent the opinion of the ZEW. 


\section{Non-technical summary:}

Beyond the fundamental incentive problems of international cooperation, climate change policy has an important political economy dimension. In the standard political economy approach, any government is motivated by the objective of maximizing its political income, i.e. the probability of being re-elected. In order to be re-elected, the government must obey the preferences of the pivotal voter, who can be approximated by the median voter in a democracy. Thus, the national median voter imposes a restriction on what would be acceptable to a government in international environmental negotiations. Ultimately, one would expect a government only to enter into agreements that are acceptable to the median voter. From a political economy point of view, thus, the median voter's willingness to pay ultimately determines the outcome of international environmental negotiations.

In this paper, we investigate the political economy conjecture for the case of the Kyoto Protocol. We have shown that U.S. withdrawal from the Kyoto Protocol is straightforward given the potential compliance costs and the domestic voters' low willingness to pay. U.S. withdrawal in 2001 had a major impact on the subsequent climate policy negotiations at Bonn and Marrakech, since it endowed remaining key parties with veto bargaining power. Canada, Australia, New Zealand, Japan and Russia, could, thus, achieve far-reaching concessions from the European Union on carbon sinks and tradability of emission rights, in particular hot air trade from the Former Soviet Union. Taking these concessions into account, Kyoto was essentially reduced to a symbolic treaty that codifies more or less business-as-usual emissions and makes compliance to a rather cheap deal. 


\title{
The Dismantling of a Breakthrough: The Kyoto Protocol - Just Symbolic Policy!
}

\author{
Christoph Böhringer and Carsten Vogt \\ Centre for European Economic Research (ZEW) \\ P.O. Box 103443 \\ D-68034 Mannheim, Germany \\ e-mail: boehringer@zew.de, vogt@zew.de
}

\begin{abstract}
We show that U.S. withdrawal from the Kyoto Protocol is straightforward under political economy considerations. The reason is that U.S. compliance costs exceed low willingness to pay for dealing with global warming in the U.S. The withdrawal had a crucial impact on the concretion of the Protocol prior to its likely ratification at the end of 2002. Remaining non-EU Parties to the Kyoto Protocol gained veto bargaining power and, thus, were successful in asserting far reaching concessions from the EU on sink credits and tradability of emission rights. Taking these concessions into account, the Kyoto Protocol was essentially reduced to a symbolic treaty that codifies more or less business-as-usual emissions and makes compliance a rather cheap deal.
\end{abstract}

JEL classification: D58, H40, Q43

Keywords: climate policy, political economy, willingness to pay 


\section{Background}

During the last decade, the issue of international cooperation in climate protection has received increasing attention in economic research. The main focus has been on the underlying economic incentives for sovereign states to enter into international environmental agreements. Since climate protection constitutes the problem of providing a global public good, it is faced with severe incentive problems for governments that try to maximize their net economic benefits. The game-theoretical literature has provided important insights into the difficulties of establishing effective and efficient cooperation on the provision of climate protection (see Finus (2001) for an overview).

Beyond the fundamental incentive problems of international cooperation, climate change policy has an important political economy dimension. In the standard political economy approach, any government is motivated by the objective of maximizing its political income, i.e. the probability of being re-elected. In order to be re-elected, the government must obey the preferences of the pivotal voter, who can be approximated by the median voter in a democracy. Thus, the national median voter imposes a restriction on what would be acceptable to a government in international environmental negotiations. Ultimately, one would expect a government only to enter into agreements that are acceptable to the median voter. From a political economy point of view, thus, the median voter's willingness to pay ultimately determines the outcome of international environmental negotiations. Surprisingly, this fact has been widely ignored in the literature (one notable exception is Congleton (1992)).

We investigate the political economy conjecture for the case of the Kyoto Protocol. This Protocol was negotiated in 1997 during the Third Conference of the Parties (COP3) to the United Nations Framework Convention of Climate Change. It requires industrialized countries (as listed in its Annex B) to limit their emissions of greenhouse gases (GHG), most notably $\mathrm{CO}_{2}$ from fossil fuel combustion. Initially, the Kyoto Protocol was supposed to provide a large cutback in business-as-usual emissions for the developed world and, therefore, was celebrated as a breakthrough in international climate protection (Oberthür and Ott (1999)).

Based on calculations with an established computable general equilibrium model of global trade and energy use, we show that the Kyoto treaty - in its original from - would have not 
only effected a substantial cutback in the developed world's business-as-usual emissions but also imposed non-negligible costs for major signatory countries. In our analysis, we use the associated per-capita costs of implementing Kyoto as a measure for the required willingness to pay for having such a climate policy enacted.

The Kyoto conference in 1997 left open several crucial aspects of concrete implementation, especially with respect to carbon sinks, i.e. forests and agricultural soils that store $\mathrm{CO}_{2}$, and the question of full versus restricted tradability of emission rights across Annex B countries. Re-negotiations during COP6 at Bonn (June 2001) and COP7 at Marrakech (November 2001) led to a generous accounting of carbon sinks and unrestricted trade in emissions rights. Particularly free permit trade accommodates larger cuts in overall compliance costs because Russia and Ukraine can sell huge amounts of surplus emission rights (so called "hot air") which was ceded to them in the original Kyoto deal. We show that even under these relaxed constraints, implementation of the Kyoto Protocol would still have been quite costly for the U.S. Since public opinion polls in the U.S. indicate a rather low willingness to pay for climate policy and re-negotiation leeway had been exhausted, the withdrawal of the U.S. government from the Kyoto Protocol in March 2001 does not come as a surprise from a political economy point of view.

Ironically, U.S. withdrawal can be regarded as ultimate impetus for the ratification of the Kyoto Protocol. The reason is the so-called "double trigger" for entering into force of the Protocol. On the one side, at least 55 countries have to ratify the treaty by their national parliaments. On the other side, those countries which ratify the treaty have to account for at least $55 \%$ of the $\mathrm{CO}_{2}$ emissions in 1990 (the Protocol's baseyear). Since the U.S. is by far the biggest emitter of $\mathrm{CO}_{2}$ among Annex B parties, ratification of the Kyoto Protocol after U.S. withdrawal requires approval of the remaining major parties. More specifically, it was no longer possible for the Kyoto Protocol to enter into force the without participation of Russia or the country group of Canada, Australia, New Zealand and Japan. After U.S. withdrawal, these countries used their veto bargaining power in the subsequent climate negotiations at Bonn (June 2001) and Marrakech (November 2001) to obtain far-reaching concessions from the European Union (EU) on the controversial issues of sink credits and emissions trading. Our simulation results show that these concessions reduce Kyoto to a symbolic treaty. Ratification of the treaty for the remaining Annex B countries now comes at virtually no economic costs while environmental effectiveness is driven close to zero. 
The remainder of the paper is organized as follows. Section 2 presents cost estimates of implementing Kyoto in its original form. Section 3 explains the recent U.S. withdrawal from a political economy perspective. Section 4 explores the implications of U.S. withdrawal on the subsequent climate policy negotiations. Section 5 concludes.

\section{Emission Reduction Constraints and Required Willingness to Pay}

In the Kyoto Protocol, industrialized countries have adopted quantified emission limitation and reduction objectives with reference to their 1990 emission levels. The column labeled "Baseline Emissions - 1990" of Table 1 lists the historic emissions for all Annex B regions, while the column labeled "Nominal Reduction" provides the reduction targets as originally foreseen by the Protocol. For reasons of data availability, we apply the GHG reduction targets to $\mathrm{CO}_{2}$ only, which is by far the most important GHG among industrialized countries.

Table 1: Baseline emissions, percentage reduction, absolute cutbacks

\begin{tabular}{|c|c|c|c|c|c|}
\hline \multirow[t]{2}{*}{ Region } & \multicolumn{2}{|c|}{$\begin{array}{l}\text { Baseline Emissions } \\
(\mathrm{MtC})^{\mathrm{a}}\end{array}$} & \multirow[t]{2}{*}{$\begin{array}{l}\text { Nominal Reduction } \\
\quad \text { (\% wrt 1990) }\end{array}$} & \multirow[t]{2}{*}{$\begin{array}{l}\text { Effective Reduction } \\
\quad(\% \text { wrt 2010) }\end{array}$} & \multirow{2}{*}{$\begin{array}{c}\text { Absolute } \\
\text { Cutback } \\
\text { (MtC wrt 2010) }\end{array}$} \\
\hline & 1990 & 2010 & & & \\
\hline AUN & 88 & 130 & -6.8 & 27.7 & 36 \\
\hline CAN & 127 & 165 & 6.0 & 27.7 & 46 \\
\hline EUR & 929 & 1041 & 7.8 & 17.7 & 184 \\
\hline JPN & 269 & 331 & 6.0 & 23.6 & 78 \\
\hline EEC & 301 & 227 & 7.1 & -23.2 & -53 \\
\hline FSU & 1036 & 713 & 0.0 & -45.3 & -323 \\
\hline Total U.S. out ${ }^{\mathrm{b}}$ & 2750 & 2607 & 5.0 & -0.7 & -32 \\
\hline USA & 1347 & 1809 & 7.0 & 30.8 & 556 \\
\hline Total U.S. in ${ }^{\mathrm{c}}$ & 4097 & 4416 & 5.0 & 11.9 & 525 \\
\hline $\begin{array}{ll}\text { Key: } & \text { AUN - Aus } \\
& \text { JPN - Japa }\end{array}$ & $\begin{array}{l}\text { ralia and } \\
\text { EEC - C }\end{array}$ & $\begin{array}{l}\mathrm{v} \text { Zealand } \\
\mathrm{al} \text { and Ea }\end{array}$ & $\begin{array}{l}\text { CAN - Canada, EUR } \\
\text { tern Europe, FSU - Fo }\end{array}$ & $\begin{array}{l}\text { OECD Europe (incl. } \\
\text { mer Soviet Union (inc }\end{array}$ & $\begin{array}{l}\text { A), } \\
\text { kraine). }\end{array}$ \\
\hline
\end{tabular}

The reduction targets with respect to 1990 are only nominal in the sense that they apply to historic emission levels. Since these targets will not become legally binding before the Kyoto commitment period (2008-2012), the appropriate reference for the effective cutback requirements are the business-as-usual $(B a U)$ emissions during the commitment period. The column labeled "Baseline Emissions - 2010" reports the projected BaU emissions for the 
central year 2010 based on the reference scenario of the most recent International Energy Outlook (IEO 2001) by the U.S. Department of Energy. Except for the economies in transition, which include Eastern and Central Europe (EEC) as well as the Former Soviet Union (FSU), the nominal commitments translate into much more stringent reduction requirements, since industrialized countries are projected to have economic growth accompanied by a considerable increase in GHG emissions from fossil fuel combustion. For example, Australia and New Zealand (AUN) receive emission rights that are roughly $7 \%$ higher than their 1990 reference emission levels, but in 2010 they will nevertheless face an effective cutback requirement of nearly $28 \%$ vis-à-vis their BaU emissions. Apparently, the economies in transition have been endowed with emission entitlements under the Kyoto Protocol that are well in excess of their anticipated future $\mathrm{BaU}$ emissions. As will be elaborated below, the availability of these excess emissions, referred to as "hot air", will crucially affect the potential compliance costs of OECD countries under the Kyoto Protocol.

The column labeled "Absolute Cutback" converts the effective percentage reduction into absolute cutback requirements. An assessment of Table 1 with respect to the implementation of the Kyoto Protocol in its original form (i.e. U.S. compliance and $O L D$ targets) indicates that the Kyoto Protocol demands a substantial cutback of $\mathrm{BaU}$ emissions in the industrialized world. Even in the case of unrestricted Annex B trade in emission rights, which would allow for the full availability of hot air from EEC and FSU, aggregate Annex B emissions are supposed to fall by roughly $12 \%$ as compared to $\mathrm{BaU}$ in 2010 .

Given some indication of the voter's actual willingness to pay for climate protection, the key issue regarding political acceptance of the Kyoto Protocol are the compliance costs associated with the implementation of the Kyoto targets. These compliance costs can be readily interpreted as the required willingness to pay to have the Kyoto targets enacted. To measure compliance costs, we employ an established computable general equilibrium model of world trade and energy use that simulates the economic adjustment costs to emission constraints. The general equilibrium approach provides a consistent and comprehensive framework for studying price-dependent interactions between the energy system and the rest of the economy. It has become the standard tool for the analysis of the economy-wide impacts of greenhouse gas abatement policies on resource allocation and the associated implications for incomes of economic agents (see Weyant (1999) for a recent survey on model-based studies). 
The concrete multi-sector, multi-region model underlying our analysis has been extensively used in the past to quantify the economic impacts of alternative GHG abatement strategies (see e.g. Böhringer (2000), Rutherford and Paltsev (2000), Böhringer (2002), Böhringer and Rutherford (2002), Böhringer and Löschel (2002)). For the sake of brevity, we abstain here from presenting a comprehensive appendix on the model algebra and the model parameterization, which can be downloaded from ftp://ftp.zew.de/pub/zew-docs/div/kppolecon.pdf. We use this model to quantify the economic and environmental consequences of abatement policies with respect to the $B a U$ situation in 2010, which is based on most recent projections of the U.S. Department of Energy (IEO (2001)). Due to a dominant supply position stemming from huge amounts of hot air (see Table 1), FSU is treated as monopolist on imperfectly competitive international permit markets (Westkog (1996)). As a monopolist, FSU restricts permit supply by charging a mark-up over its marginal abatement cost (which are zero for hot air) to maximize profits.

Table 2 summarizes the effects for two alternative designs of implementing Kyoto on consumption and global emissions. Scenario NTRin_OLD considers the implementation of the Kyoto Protocol based on the original reduction targets, U.S. compliance and fully domestic action (i.e. no trade in emission rights). Scenario TRDin_NEW reflects the case in which the original Kyoto targets are adjusted for sink credits, U.S. complies, and emissions are fully tradable across Annex B regions. Under NTRin_OLD adjustment costs - measured in percentage loss of $\mathrm{BaU}$ consumption - range from $0.2 \%$ for EUR to $1.5 \%$ for CAN indicating differences in the effective cutback requirements, the ease of carbon substitution in production and consumption, and indirect losses or benefits through changes in international prices (terms-of-trade effects). The latter are the reason why EEC and FSU as well as ROW are affected by abatement policies of trading partners even though they do not face a binding emission constraint. Terms-of-trade effects work primarily through the decline of international fuel prices following the drop in energy demand under emission reduction policies: As a net fuel importer, EEC benefits from cheaper energy imports, while FSU and ROW, which are net fuel exporters, are negatively affected (see Böhringer and Rutherford (2002) for a detailed discussion). When we convert the percentage changes in consumption into equivalent payments per capita, the specific costs for abating OECD regions range from $23 \mathrm{USD} /$ capita for EUR to $162 \mathrm{USD} /$ capita for CAN. The compliance costs for the U.S. amounts to 92 USD. 
Table 2: Key economic and environmental impacts of implementing the Kyoto Protocol

\begin{tabular}{|c|c|c|c|}
\hline \multicolumn{2}{|l|}{ Region } & NTRin_OLD & TRDin_NEW \\
\hline & & \multicolumn{2}{|c|}{ Consumption Change in $\%$ vs. $B a U$} \\
\hline AUN & Australia and New Zealand & -1.18 & -0.63 \\
\hline CAN & Canada & -1.48 & -0.50 \\
\hline EUR & Europe & -0.17 & -0.10 \\
\hline JPN & Japan & -0.26 & -0.06 \\
\hline EEC & Central and Eastern Europe & 0.49 & 2.16 \\
\hline FSU & Former Soviet Union & -0.93 & 2.78 \\
\hline USA & USA & -0.51 & -0.27 \\
\hline ROW & Rest of the World & -0.35 & -0.13 \\
\hline \multicolumn{2}{|l|}{ TOTAL } & -0.24 & -0.06 \\
\hline \multicolumn{4}{|c|}{ Consumption change in $\mathrm{USD}_{97}$ per capita } \\
\hline AUN & Australia and New Zealand & -114 & -62 \\
\hline CAN & Canada & -162 & -53 \\
\hline EUR & Europe & -23 & -13 \\
\hline JPN & Japan & -53 & -13 \\
\hline EEC & Central and Eastern Europe & 8 & 36 \\
\hline FSU & Former Soviet Union & -12 & 34 \\
\hline \multirow[t]{2}{*}{ USA } & USA & -92 & -49 \\
\hline & & \multicolumn{2}{|c|}{ Emission reduction in \% vs. $B a U$} \\
\hline TOTAL & & 9.6 & 4.4 \\
\hline
\end{tabular}

Scenario TRDin_NEW provides revised cost estimates that account for the recent outcome of Bonn in June 2001 and Marrakech in November 2001: Besides the generous accounting of carbon sink credits, parties have implicitly agreed on unrestricted Annex B emissions trading. These concretions to the Kyoto Protocol substantially lower compliance costs but would still impose a significant consumption loss for AUN, CAN and the U.S. with an annual per-capita cost of 62 USD (AUN), 53 USD (CAN) and 49 USD.

The figures presented in Table 2 are based on central case elasticities (see Table A.7 of appendix). To evaluate the sensitivity of our model estimates to uncertainties in the parameterization space, we have performed an extensive sensitivity analysis. The sensitivity analysis confirms robustness of results with respect to key elasticities and alternative baseline assumptions. In the remainder of our analysis, we, therefore, interpret the per-capita cost figures of Table 2 as required WTP of countries that are engaged in the climate change negotiations. 


\section{The Rationale behind U.S. Withdrawal}

We have argued that in a political economy context, governments will keep the preferences of their voters in mind. They will not agree upon treaties that would not find the support of the median voter at home. To investigate the prospects of GHG abatement policies, we must compare the required willingness to pay (WTP) with the actual (revealed) WTP for climate protection by the domestic median voter. The required WTP for the U.S. as quantified in Table 2 appears substantial even for Kyoto in its re-negotiated form. This raises the question of whether actual WTP for mitigating climate change in the U.S. ever reached such high levels.

Unfortunately, quantitative estimates of the demand for mitigating climate change are sparse in the literature. There are two established methods that could be used for measuring environmental preferences with respect to climate change. First, one could try to estimate the demand for climate protection from some theoretical model, e.g. a public good model. This approach is taken by Murdoch and Sandler (1997) for the case of ozone layer depletion. However, their study stands as a rare, if not unique attempt to measure environmental demand in the context of a global public good. Second, one could try to detect people's preferences by asking them directly, e.g. by using the framework of a contingent valuation study. This type of study has also been used extremely seldom to address the question of environmental demand in an international context. We only know of one contingent valuation study in this context, that has been performed for Switzerland (see Ledergerber et al. (1995)).

It seems, hence, appropriate to rely on public opinion polls as reported in Tables 3 and 4 for the U.S. Some difficulties in interpretation arise with respect to the obscure category "neither willing nor unwilling". To our understanding, these respondents indicated that they do not want a change of the status quo. We therefore add them to those respondents that are opposed to higher taxes or cuts in their standard of living. The tables then clearly show that a vast majority of U.S. citizens is not willing to pay much higher taxes or to accept cuts in their standard of living in order to protect the environment.

Moreover, this fraction of respondents rose from about $60 \%$ in 1993 to about $70 \%$ in 2000. Even if we skip the category "neither willing nor unwilling", the recent polls for 2000 report a distinct majority of people that are opposed to higher eco-taxes or income losses for the sake of the environment. 
Table 3: Acceptance of high eco-taxes

\begin{tabular}{lcc}
\hline & U.S. $1993(\%)$ & U.S. $2000(\%)^{*}$ \\
\hline (1) Very willing & 7.3 & 6.17 \\
(2) Fairly willing & 32.9 & 25.45 \\
(3) Neither nor & 20.4 & 26.99 \\
(4) Fairly unwilling & 25.8 & 19.28 \\
(5) Very unwilling & 13.6 & 22.11 \\
\hline Sum (4) and (5) & 39.4 & 41.39 \\
\hline Sum (3), (4) and (5) & 59.8 & 68.38 \\
\hline
\end{tabular}

*own calculations based on unreleased raw data from ISSP (2000)

Question: How willing would you be to pay much higher taxes in order to protect the environment? Source: ISSP (1993) and ISSP (2000)

Table 4: Acceptance of cuts in standard of living

\begin{tabular}{lcc}
\hline & U.S. $1993(\%)$ & U.S. $2000(\%)^{*}$ \\
\hline (1) Very willing & 6.2 & 5.47 \\
(2) Fairly willing & 27.9 & 23.93 \\
(3) Neither nor & 24 & 26.67 \\
(4) Fairly unwilling & 26.2 & 20.51 \\
(5) Very unwilling & 15.6 & 23.42 \\
\hline Sum (4) and (5) & 41.8 & 43.93 \\
\hline Sum (3), (4) and (5) & 65.8 & 70.6 \\
\hline
\end{tabular}

*own calculations based on unreleased raw data from ISSP (2000)

Question: How willing would you be to accept cuts in your standard of living in order to protect the environment? Source: ISSP (1993) and ISSP (2000)

It must be conceded that the polls asked for the protection of the environment in general and so are not specific to the problem of climate change. However, as we can see from Table 5, the topic "Environment " is strongly dominated by other issues like "Ethics", "Crime", or "Drugs". Moreover, "global warming" is a very low ranking issue even on the environmental agenda (see Table 6 - entries show the percentage of respondents who "worried a great deal"). Hence, we can safely conclude that if willingness to pay for the protection of the environment as a whole is already low, it will be even lower for climate change protection in particular.

The Bush administration obviously perceived that compliance to Kyoto even in its "lite" version would have imposed substantial costs on the U.S. economy. Furthermore, the U.S. recognized that additional negotiation to make the Protocol acceptable to the U.S. public was not possible. The two key issues of re-negotiation, sinks and tradability, had been already very stressed in the climate negotiations prior to U.S. withdrawal. There was no more leeway 
left to further lower the U.S. target. Realizing the discrepancy between required and actual WTP for mitigating climate change, the U.S. withdrew.

Table 5: Ranking of different political topics in the U.S.

\begin{tabular}{lcc}
\hline Problem & April 2000 & January 2001 \\
\hline Ethics/ moral/ family decline/ & 7 & 13 \\
Dishonesty/ lack of integrity & 11 & 12 \\
Education & 12 & 9 \\
Crime/ violence & 5 & 7 \\
Drugs & 6 & 7 \\
Health care & 4 & 7 \\
The economy (general) & 3 & 5 \\
Taxes & 6 & 4 \\
Poverty/ hunger/ homelessness & 2 & 2 \\
Environment/ pollution & 1 & 2 \\
Lack of military defense & & \\
\hline
\end{tabular}

Question: What do you think is the most important problem facing this country today?

Source: Gallup (2001, p.4)

Table 6: Ranking of different environmental topics in the U.S.

\begin{tabular}{lcccccc}
\hline & May 1989 & April 1990 & April 1991 & Oct 1997 & April 1999 & April 2000 \\
\hline $\begin{array}{l}\text { Pollution of lakes, rivers and } \\
\text { reservoirs }\end{array}$ & 72 & 64 & 67 & & 61 & 66 \\
$\begin{array}{l}\text { Contamination of soil and water } \\
\text { by toxic waste }\end{array}$ & 69 & 63 & 62 & & 63 & 64 \\
$\begin{array}{l}\text { Air pollution } \\
\text { Loss of natural habitat for }\end{array}$ & 53 & 58 & 59 & 42 & 52 & 59 \\
$\quad$ wildlife & 51 & 53 & & 49 & 51 \\
$\begin{array}{l}\text { Ocean and beach pollution } \\
\text { Damage to the ozone layer }\end{array}$ & 51 & 43 & 49 & 33 & 44 & 49 \\
Loss of tropical rain forests & 42 & 40 & 42 & & 49 & 51 \\
Acid rain & 41 & 34 & 34 & & 29 & 34 \\
Global warming & 35 & 30 & 35 & 24 & 34 & 40 \\
\hline
\end{tabular}

Question: I'm going to read you a list of environmental problems. As I read each one, please tell me if you personally worry about this problem a great deal, a fair amount, only a little, or not at all?

The table shows the percentage of respondents who worried a great deal.

Source: Gallup (2000, p.4) 
U.S. withdrawal from the Kyoto Protocol seems to have voter's support not only under narrow WTP considerations but also under specific fairness perceptions. In fact, there has been skepticism about Kyoto in the U.S. for several years. Prior to the Kyoto conference, the U.S. Senate unanimously passed the Byrd-Hagel resolution, which makes 'meaningful participation' of developing countries a conditio sine qua non for ratification of the Kyoto Protocol. The Senate made clear that it will not accept any treaty on climate change 'unless the protocol or other agreement also mandates new specific scheduled commitments to limit or reduce greenhouse gas emissions for Developing Country Parties within the same compliance period' (Oberthür and Ott (1999), p.70). The vast majority of the American public was supportive of the Senate's reservation on ratification of the Kyoto Protocol, as is indicated by Table 7 .

Table 7: U.S. opinion on burden sharing

\begin{tabular}{lc}
\hline All countries the same changes & $70 \%$ \\
Developing countries less burden & $19 \%$ \\
Don't know & $8 \%$ \\
Both/ neither & $3 \%$ \\
\hline
\end{tabular}

Question: Some people say that since poorer countries did not cause much pollution, they should not have to bear as much of the burden in dealing with global warming. Others say that every country, rich or poor, should make the same changes in order to limit future global warming. Which of these views comes closer to your own?

Source: Princeton Survey Research/ Pew 1997, cited in:

http://www.publicagenda.org/issues/angles_graph.cfm?issue_type=environment\&id=93\& graph=mp9.gif

A U.S. survey conducted by Wirthlin in September 1998 (Wirthlin 1998) yields very similar results. When confronted with the statement: 'I do not support the Kyoto Protocol because it unfairly forces developed countries to reduce pollutants, while allowing other countries to continue polluting', $25 \%$ of the respondents agreed strongly and $43 \%$ told the interviewers they agreed somewhat. Only $30 \%$ agreed to the following statement: 'It is only fair that undeveloped countries should not be held to the same pollution standards, since they still need to catch up with the rest of the developed countries' (Wirthlin (1998), p.6).

\section{The Implications of U.S. Withdrawal}

U.S. withdrawal had a major impact on the subsequent climate negotiations, since it gave veto bargaining power to important single countries in the climate talks. Due to the "double trigger" mechanism, entry into force of the Kyoto Protocol is no longer possible without 
participation of Russia and the country group of Canada, Australia, New Zealand, and Japan. All of these regions have expressed reluctance to agree to the Protocol without major revisions to its original amendments.

After years of tedious negotiations, U.S. withdrawal paved the way for the Bonn agreement of remaining Annex B countries on the final implementation of the Kyoto Protocol. The agreement at Bonn in June 2001 (which has been confirmed at the Marrakech climate conference in November 2001) was the straightforward result of the altered bargaining situation. After U.S. withdrawal, remaining non-EU countries could strive for far-reaching concessions of the EU. The EU had always been very restrictive on the key issues of "sinks" and "tradability". With respect to the former issue, the EU demanded for a long time to exclude sinks as a means for the fulfillment of reduction targets in the first commitment period of the Kyoto Protocol 2008-2012. With respect to the latter issue, it always favored strict caps on tradability to suppress trade in hot air.

Table 8 presents quantitative evidence on the economic and environmental impacts of emissions trading (NTR versus TRD), U.S. withdrawal (in versus out), and the adjustment of the Kyoto targets for sink credits $(O L D$ versus $N E W)$. These changes to the original Kyoto Protocol have drastically reduced compliance costs. The downside is that the environmental effectiveness of the Protocol is driven close to zero as hot air from FSU can be fully traded (see also Böhringer (2002)).

In our political economy context, one can assert that U.S. withdrawal has significantly promoted the ratification of the Kyoto Protocol because it essentially reduces compliance for remaining Annex B countries to mere symbolic policy.

Table 8 also provides interesting insights on the self-declared "climate leadership" of the EU. In cross-country comparison of implementation costs, EU ranks lowest. WTP for the implementation of Kyoto in its original form would have required a WTP which is five times higher in AUN and seven times higher in CAN than in EUR. It is unlikely that WTP in these countries would have ever reached such high levels. For the EU, however, it has been very easy to act as a protagonist of ambitious reduction targets, since the implied costs for the EU would have been relatively low. 
Table 8: Economic and environmental impacts of implementing the Kyoto Protocol

\begin{tabular}{|c|c|c|c|c|}
\hline & NTRin_OLD & NTRout_OLD & NTRout_NEW & TRDout_NEW \\
\hline \multicolumn{5}{|c|}{ Consumption change in $\%$ vs. $B a U$} \\
\hline AUN & -1.18 & -1.09 & -0.93 & -0.29 \\
\hline CAN & -1.48 & -0.62 & -0.29 & -0.13 \\
\hline EUR & -0.17 & -0.24 & -0.19 & -0.06 \\
\hline JPN & -0.26 & -0.34 & -0.22 & -0.05 \\
\hline EEC & 0.49 & 0.27 & 0.22 & 0.75 \\
\hline FSU & -0.93 & -0.69 & -0.59 & 0.38 \\
\hline USA & -0.51 & 0.01 & 0.01 & 0.00 \\
\hline ROW & -0.35 & -0.19 & -0.15 & -0.03 \\
\hline TOTAL & -0.24 & -0.12 & -0.09 & -0.01 \\
\hline \multicolumn{5}{|c|}{ Consumption change in $\mathrm{USD}_{97}$ per capita } \\
\hline AUN & -114 & -107 & -90 & -28 \\
\hline CAN & -162 & -68 & -32 & -15 \\
\hline EUR & -23 & -31 & -24 & -8 \\
\hline JPN & -53 & -67 & -43 & -9 \\
\hline EEC & 8 & 4 & 3 & 12 \\
\hline FSU & -12 & -9 & -7 & 5 \\
\hline USA & -92 & - & - & - \\
\hline \multicolumn{5}{|c|}{ Emission reduction in \% vs. $B a U$} \\
\hline TOTAL & 9.6 & 2.8 & 2.3 & 0.7 \\
\hline
\end{tabular}

\section{Conclusion}

We tried to shed some light on recent developments in the climate change negotiations from a political economy point of view. We have shown that U.S. withdrawal from the Kyoto Protocol is straightforward given the potential compliance costs and the domestic voters' low willingness to pay.

U.S. withdrawal in 2001 had a major impact on the subsequent climate policy negotiations at Bonn and Marrakech since it endowed remaining key parties with veto bargaining power. Canada, Australia, New Zealand, Japan, and Russia thus could achieve far-reaching concessions from the EU on carbon sinks and tradability of emission rights, particularly hot air trade from the Former Soviet Union. Taking these concessions into account, Kyoto reduces to a symbolic treaty that codifies more or less business-as-usual emissions and makes compliance a rather cheap deal. 


\section{REFERENCES}

Böhringer, C. (2000), Cooling Down Hot Air - A Global CGE Analysis of Post-Kyoto Carbon Abatement Strategies, Energy Policy, 28, 779-789.

Böhringer, C. (2002), From Kyoto to Bonn: From Little to Nothing?, The Energy Journal 23 (2), 51-71.

Böhringer, C. and A. Löschel (2002), Economic Impacts of Carbon Abatement Strategies, in: C. Böhringer, M. Finus and C. Vogt (eds.), Controlling Global Warming - Perspectives from Economics, Game Theory and Public Choice, Cheltenham: Edward Elgar, (New Horizons in Environmental Economics) (forthcoming)

Böhringer, C. and T. Rutherford (2002), Carbon Abatement and International Spillovers, Environmental and Resource Economics (forthcoming).

Congleton, R.D. (1992), 'Political Institutions and Pollution Control', Review of Economics and Statistics, 74 (3), 412-21.

Finus, M. (2001), Game Theory and International Environmental Cooperation, Edward Elgar, Cheltenham, UK.

Gallup (2000), Poll Releases September 25 2000, Princeton: The Gallup Organization, http://www.gallup.com/poll/releases/pr000925.asp

Gallup (2001), Poll Releases February 5 2001, Princeton: The Gallup Organization, http://www.gallup.com/poll/releases/pr010205.asp

IEO (2001), International Energy Outlook 2001, U.S. Department of Energy, Energy Information Administration, http://www.eia.doe.gov.

International Social Science Panel (ISSP) (1993), Environment I, Codebook ZA Study 2450, Central Archive for Empirical Social Research at the University of Cologne, http://www.gesis.org/ZA/

International Social Science Panel (ISSP) (2000), Central Archive for Empirical Social Research at the University of Cologne, http://www.gesis.org/ZA/

Ledergerber, Elmar, Walter Ott, Rolf Iten, Daniel Peter and Barbara Jäggin (1994), Zahlungsbereitschaft für die Verhinderung einer globalen Klimaänderung (The Willingness to Pay for Prevention of Global Climate Change), Bern: Bundesamt für Energiewirtschaft

Murdoch, J.C. and T. Sandler (1997), 'The Voluntary Provision of a Pure Public Good: The Case of Reduced CFCs Emissions and the Montreal Protocol', Journal of Public Economics, 63, 331-349. 
Oberthür, S. and H. Ott (1999), The Kyoto Protocol: International Climate Policy for the $21^{\text {st }}$ Century, Berlin: Springer.

Rutherford, T.F. and S.V. Paltsev (2000), GTAP-Energy in GAMS, University of Colorado, Working Paper 00-2, http://debreu.colorado.edu/download/gtap-eg.html

UNFCCC (2001), United Nations Framework Convention on Climate, Review of the implementation of commitments and of other provisions of the Convention, FCCC/CP/2001/L.7, VI, 5.

Westkog, H. (1996), 'Market Power in a System of Tradable CO2-quotas', Energy Journal, $17,85-103$.

Weyant, J. (ed.) (1999), The Costs of the Kyoto Protocol: A Multi-Model Evaluation, The Energy Journal, Special Issue.

Wirthlin (1998), The Wirthlin Report September 1998, Wirthlin Worldwide, http://209.204.197.52/publicns/report/wr9809.html 